\title{
David Oliver: Why I let some patients stay longer in hospital
}

\author{
David Oliver consultant in geriatrics and acute general medicine, Berkshire
}

I have a confession: I sometimes allow patients to stay an extra day or three in hospital, even when they're technically stable enough to leave. I've spoken to many other secret transgressors, but it's still a hard thing to admit.

Yes: I know that it's bad. England has relatively few acute beds. ${ }^{1}$ We've lost them rapidly, while emergency admissions and delayed transfers have risen inexorably. ${ }^{2}$

Overcrowding hurts. ${ }^{3}$ Hospitals become less efficient and safe when bed occupancy is high. ${ }^{4}$ Four hour NHS targets for emergency departments cause huge pressure. Beds are scarce, as well as cost intensive, and newer, sicker patients at the front door will always need them more.

Prolonged stays in hospital can harm patients by causing dependence. They can lead to missed "windows" to get people home. I've written extensively about the importance of good discharge planning. ${ }^{5}$ I've advised many hospitals on coordinated working to prevent admissions or to help older patients with complex needs leave sooner. So, am I a hypocrite for letting people stay for "soft" reasons?

Doctors are in a people business-or they're in the wrong job. Population health and system leadership matter, but the foundation of our profession is still care for individuals. In ethical terms ${ }^{6}$ : should equity in allocation of scarce resources always outflank respect for autonomy, despite all that we hear about person centred care based on individual needs?

If patients need ongoing rehabilitation or social care I'd like to ensure that they get it, however full the hospital. If not, they risk permanent disability or badly supported, distressing discharge, avoidable readmission, and more stress to carers struggling for any sense from the system. ${ }^{78}$

If it's late at night and older patients are going home alone, I sometimes keep them until morning, especially after falls. Other reasons include patients needing an extra day to regain confidence or to wait until a supportive relative is around, or if they know from experience of their own condition and multiple admissions that discharge is more likely to work if briefly postponed. Perhaps a patient doesn't want that community hospital because his wife died there, and memories abound. Maybe a patient's 85 year old husband prefers a nursing home he can visit on public transport.

I've had numerous donations, cards, and funeral invitations from families of patients who chose to remain on the ward for palliative care even though they had been offered support to die out of hospital. Was it wrong to exercise some humane discretion?

It will be a sad day when we judge acute hospital doctors' performance principally by how many admissions they stop and how quickly they send people home. I've confessed, but I think I'm unrepentant.

Competing interests: I have read and understood BMJ policy on declaration of interests and have no relevant interests to declare. Provenance and peer review: Commissioned; not externally peer reviewed.

Appleby J. The hospital bed: on its way out? BMJ 2013:346:f1563.

2 King's Fund. Quarterly monitoring report 16: how is the NHS performing? Jul 2015. http: //qmr.kingsfund.org.uk/2015/16/.

3 College of Emergency Medicine. Crowding in emergency departments. Jun 2014. www. rcem.ac.uk/Shop-Floor/Clinical\%20Guidelines/College\%20Guidelines.

4 NHS England. Transforming urgent and emergency care services in England. Aug 2015. www.england.nhs.uk/wp-content/uploads/2015/06/trans-uec.pdf.

5 Oliver D, Foot C, Humphries R. Section 6: Good discharge planning and post-discharge support. In: Making health and care systems fit for an ageing population. King's Fund 2014. www.kingsfund.org.uk/sites/files/kf/field/field_publication_file/making-health-caresystems-fit-ageing-population-oliver-foot-humphries-mar14.pdf.

6 Gillon R. Medical ethics: four principles plus attention to scope. BMJ 1994;309:184

7 HealthWatch England. Safely home: what happens when older people leave hospital settings? July 2015. http://www.healthwatch.co.uk/sites/healthwatch.co.uk/files/170715 healthwatch_special_inquiry_2015_1.pdf.

8 Ellins J, Glasby J, Tanner D, et al. Understanding and improving transitions of older people: a user and carer centred approach. National Institute for Health Research 2012 http://www.birmingham.ac.uk/documents/news/sdotransitions-report.pdf.

Cite this as: BMJ 2015;351:h5225

๑ BMJ Publishing Group Ltd 2015 